\title{
A novel strategy for efficient production of anti-V3 human scFvs against HIV-1 clade C
}

\author{
Rajesh Kumar ${ }^{1 \dagger}$, Raiees Andrabi ${ }^{1 \dagger}$, Ashutosh Tiwari ${ }^{1,4}$, Somi Sankaran Prakash', Naveet Wig ${ }^{2}$, Durgashree Dutta ${ }^{1}$,
} Anurag Sankhyan', Lubina Khan ${ }^{1}$, Subrata Sinha ${ }^{1,3^{*}}$ and Kalpana Luthra ${ }^{1 *}$

\begin{abstract}
Background: Production of human monoclonal antibodies that exhibit broadly neutralizing activity is needed for preventing HIV-1 infection, however only a few such antibodies have been generated till date. Isolation of antibodies by the hybridoma technology is a cumbersome process with fewer yields. Further, the loss of unstable or slowly growing clones which may have unique binding specificities often occurs during cloning and propagation and the strongly positive clones are often lost. This has been avoided by the process described in this paper, wherein, by combining the strategy of EBV transformation and recombinant DNA technology, we constructed human single chain variable fragments (scFvs) against the third variable region (V3) of the clade C HIV-1 envelope.

Results: An antigen specific phage library of 7000 clones was constructed from the enriched V3- positive antibody secreting EBV transformed cells. By ligation of the digested SCFv DNA into phagemid vector and bio panning against the HIV-1 consensus C and B V3 peptides followed by random selection of 40 clones, we identified 15 clones that showed $V 3$ reactivity in phage ELISA. DNA fingerprinting analysis and sequencing showed that 13 out of the 15 clones were distinct. Expression of the positive clones was tested by SDS-PAGE and Western blot. All the 13 anti-V3 scFvs showed cross-reactivity against both the clade C and B V3 peptides and did not show any reactivity against other unrelated peptides in ELISA. Preliminary neutralization assays indicated varying degrees of neutralization of clade $C$ and $B$ viruses. EBV transformation, followed by antigen selection of lines to identify specific binders, enabled the selection of phage from un-cloned lines for scFv generation, thus avoiding the problems of hybridoma technology. Moreover, as the clones were pretested for antigen binding, a comparatively small library sufficed for the selection of a considerable number of unique antigen binding phage. After selection, the phage clones were propagated in a clonal manner.
\end{abstract}

Conclusions: This strategy can be efficiently used and is cost effective for the generation of diverse recombinant antibodies. This is the first study to generate anti-V3 scFvs against HIV-1 Clade C.

Keywords: HIV-1, Clade C, V3, scFv

\section{Background}

There is a rapid increase in the number of human immunodeficiency virus (HIV-1) infected individuals worldwide and so far we have met with little success in slowing down or preventing the progression of this pandemic disease. In order to use broadly neutralizing

\footnotetext{
*Correspondence: subrata.sinha@nbrc.ac.in; kalpanaluthra@gmail.com ${ }^{\dagger}$ Equal contributors

'Department of Biochemistry, All India Institute of Medical Sciences, New Delhi, India

${ }^{3}$ National Brain Research Centre, Manesar, India

Full list of author information is available at the end of the article
}

antibodies as effective reagents for passive immunotherapy to slow or to halt the disease progression in HIV-1 infected individuals and for immunogen design for vaccination to prevent the infection, the generation of large numbers of human HIV-1 specific monoclonal antibodies is desirable. Although a few human broadly neutralizing antibodies (bNAbs) to HIV-1 exist [1-10], these antibodies have limited reactivity against non-clade $B$ viruses, which are responsible for more than $85 \%$ of the infections worldwide [4]. Few bNAbs exist so far, that are effective against the clade $C$ viruses, which include the 4E10, antibodies from the CAPRISA cohort and the recently isolated

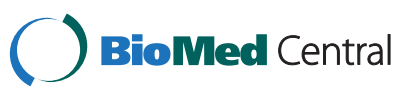

(c) 2012 Kumar et al.; licensee BioMed Central Ltd. This is an Open Access article distributed under the terms of the Creative Commons Attribution License (http://creativecommons.org/licenses/by/2.0), which permits unrestricted use, distribution, and reproduction in any medium, provided the original work is properly cited. 
monoclonal antibodies PG9, PG16 and VRC01 [9-12] . In order to evaluate their utility in combating HIV-1 infection, and to tackle the problems posed by the extensive diversity of HIV-1, it is essential to generate a large panel of human anti-HIV-1 antibodies of different specificities. Further, it may be necessary to evaluate several antibodies to find rare but highly effective molecules.

The methods used for the generation of human monoclonal antibodies include the hybridoma technology, recombinant technology by phage display and the recently employed techniques such as single B cell sorting followed by amplification of heavy and light chain genes $[8,13,14]$. Generation of antibodies by the conventional hybridoma technology is not adequate enough to meet the challenge of assessing large numbers of human monoclonal antibodies from HIV-1 infected individuals at various stages of their clinical course. Our approach to the problem has been to combine the antigen specific pre-selection of EBV transformed B cells with the construction of a phage library.

Phage display is a scalable method for antibody production against a wide variety of antigens [15-17]. Investigators are using this technology for the production of antibodies with the desired isotype specificities and affinity for research, clinical and industrial applications. Antibody gene variable regions are amplified and expressed on the surface of filamentous bacteriophage as a fusion protein [14] and a number of antibodies can be produced from a single library and can be expressed and produced in a prokaryotic system. The major drawback in this technology is the requirement for the construction of large sized phage libraries $\left(10^{9}-10^{10}\right)$ with an optimum diversity because the diversity of these libraries primarily determines the successful isolation of the desired antibodies. Construction of such large libraries requires a number of ligation and electroporation reactions. Screening of positive clones from these libraries generally require at least three to seven rounds of biopanning to select specifically binding clones $[18,19]$. It is also difficult to maintain such large sized libraries. Keeping all these factors in mind we have described here a simple and efficient method for the production of human monoclonal antibodies using a combinational approach of EBV transformation, antigen preselection and phage display technology. A similar approach was previously used by Kempf et al. to isolate Fabs to the gp120 of HIV-1 [20]. Here, we adopted a modified strategy and isolated for the first time, human anti-V3 scFvs from the EBV transformed lymphocytes of a clade C HIV-1 infected patient. This method can be used to produce large panels of viral specific phage libraries in less time and in a cost effective manner.

A limited number of monoclonal antibodies are generated against the HIV-1 Clade $\mathrm{C}$ which is the most predominant subtype worldwide and in India [21]. The V3 region of HIV-1 gp120 is an important target to induce neutralizing antibodies against different strains of HIV-1. It exhibits a high degree of sequence variability in the most structurally conserved region of the HIV-1 envelope $[22,23]$ and it interacts with the co-receptors CCR5 and CXCR4 [7,24,25]. In this study, we constructed a scFv library from the EBV transformed B cells of an HIV-1 infected patient \#254, reactive to the third variable (V3) region of gp120 of HIV-1 clade C. The plasma sample of this patient was previously tested and found to exhibit cross neutralizing activity against a standard panel of pseudoviruses of different clades (Table 1) and also had cross reactive binding antibodies to clade $\mathrm{C}$ and $\mathrm{B}$ V3 peptides $[26,27]$. The modified strategy used here employing EBV transformation; antigen preselection followed by phage library construction enabled the successful selection of human monoclonal recombinant scFvs specific to the V3 antigen of HIV-1. Construction of human $\mathrm{scFv}$ phage library from these antigen preselected B cells led to an efficient and cost effective approach for the production of anti-V3 scFvs.

\section{Results}

Viral neutralization and cross reactive binding activity of the patient plasma \#254

The plasma antibodies of the HIV-1 infected patient \#254 displayed neutralizing activity against 8 out of 10 HIV-1 viruses from subtype-A, B and C (Table 1). The plasma sample also showed a cross subtype-B and $C$ binding reactivity in context of the anti-V3 loop directed antibodies (Figure 1).

\begin{tabular}{|c|c|c|c|c|}
\hline Sr. No. & Virus & Tier & Subtype & ID50 \\
\hline 1 & 92RW009 & 1 & $A$ & 74 \\
\hline 2 & Q461 & 1 & A & 98 \\
\hline 3 & SF162 & 1 & B & 1296 \\
\hline 4 & JRCSF & 1 & B & 103 \\
\hline 5 & Du156.12 & 2 & C & 206 \\
\hline 6 & ZM53M.PB12 & 2 & C & $<60$ \\
\hline 7 & ZM109F.PB4 & 2 & C & 104 \\
\hline 8 & JRFL & 2 & B & $<60$ \\
\hline 9 & RHPA4259.7 & 2 & B & 446 \\
\hline 10 & TRO.11 & 2 & B & 162 \\
\hline
\end{tabular}

The cross neutralizing activities of plasma antibodies from HIV-1 infected drug naïve sample \#254 against a panel of subtype-A, B, C tier 1 and 2 viruses indicated on left. The numerical values on the extreme right of table represent the mean $50 \%$ neutralization titers (ID50) defined as the reciprocal dilution of plasma which neutralized $50 \%$ of viral infection in the assay. For clarity, this information is coded; ID50> 1000 (Bold), ID50= 100-I000 (Bold Italic), ID50= 61-100 (Italic) and ID50<60, where $50 \%$ neutralization was not reached. Each experiment was performed at least two independent times and in duplicates. 


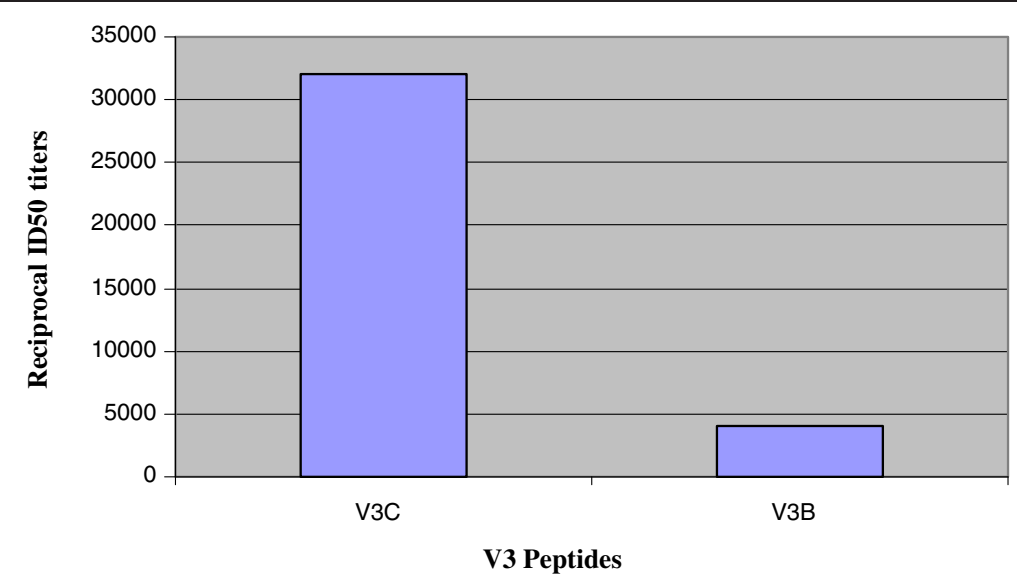

Figure 1 Level of Anti V3 antibodies in patient plasma (\#254). 50\% reciprocal binding titer of the plasma of the patient (\#254) against consensus clade $C$ and B V3 peptides. The results depict the average OD values of three independent experiments.

\section{EBV transformation}

A total of 4.8 million PBMCs were isolated from the HIV-infected patient (\# 254) and EBV transformed in 48 wells of a 96 well culture plate (Figure 2). After 2 weeks, the cultures were screened (first screening) for the presence of anti-V3 antibodies and 7/48 wells showed high V3 binding reactivity with $\mathrm{OD}>2$. Cells from these $7 \mathrm{~V} 3$ positive wells were expanded to a 24 well plate and after a second screening, cells from 5 out of 7 wells showing V3 binding with OD > 0.6 were expanded in a six-well plate, pooled and finally transferred to a T- 25 flask. In the 3rd (final) screening of the cells in the flask, the cells showed high reactivity to V3 $(\mathrm{OD}>1)$ (Table 2). These V3 positive (enriched) cells were processed for recombinant anti-V3 scFv generation.

\section{Phage library construction}

Total RNA from the V3 enriched antibody producing B cells of the patient \#254 was isolated. A total of 200ng of RNA was reverse transcribed to cDNA. Use of random hexamer and oligo $\mathrm{dT}$ in the cDNA synthesis process was shown to be more effective than either of them alone or the $3^{\prime}$ primers $[15,20]$. It also enhanced the chances of amplification of the antibody genes even when the amount of RNA is low [15]. A total of 54 combinations were used to amplify the heavy and light chains (24 for $\mathrm{VH}$ and 30 for VL). Among the 24 combinations of heavy chains, 18 were successfully amplified. The heavy chains VH1, VH4, VH5 and VH6 were preferentially more expressed while $\mathrm{VH} 2$ and $\mathrm{VH} 3$ were very less expressed (Figure 3A). All the 30 kappa light chain combinations were successfully amplified and expressed almost at the same level, except for VLK2, which were relatively less expressed (Figure $3 \mathrm{~B}$ ). A heavy chain and light chain pool was made by mixing equal concentration of each combination (50ng) irrespective of their expression level, so that each combination of the heavy chain has an equal probability to combine with the light chain and vice versa and to avoid the predominant expression of one antibody subclass and finally to have new combinations of antibodies for a particular antigen that are naturally not elicited during the natural course of infection. A final pull through PCR was performed using the forward and reverse primers. These scFvs were then ligated into the pCANTAB-5E vector that contains the Sfi1 and NotI sites (Figure 3). The ligated product was transformed into TG1 using calcium chloride mediated transformation. The incubation time after the heat shock treatment during transformation was maintained for a maximum of $40 \mathrm{~min}$ to avoid repetition of similar types of clones in the library. We obtained 200-300 transformed colonies per plate. A total of 7000 colonies were obtained with 400ng of digested scFv DNA that were ligated into $1 \mu \mathrm{g}$ of phagemid vector. The ligated DNA was transformed into E.coli TG1.

\section{Diversity of the phage antibody library}

To check the diversity of antibodies in the library, we randomly selected 10 clones from the unselected library. Amplification of these $10 \mathrm{scFvs}$ by PCR, followed by digestion with BstN1 and comparing their DNA fingerprint patterns showed that $9 / 10$ clones were distinct from each other. Clone 3 and clone 6 showed identical DNA fingerprinting patterns (Figure 4).

We further confirmed the diversity of the antibody fragments by DNA sequence analysis of 29 randomly selected $\mathrm{scFv}$ clones from the unselected library which showed high diversity of clones i.e. $73 \%(21 / 29)$ in the library. The heavy chain $(\mathrm{VH})$ sequences showed a limited diversity, IGVH4 (13/29) and IGVH5 (15/29) were the most preferentially represented $\mathrm{VH}$ sequences that combined with all the representatives of IGHD 


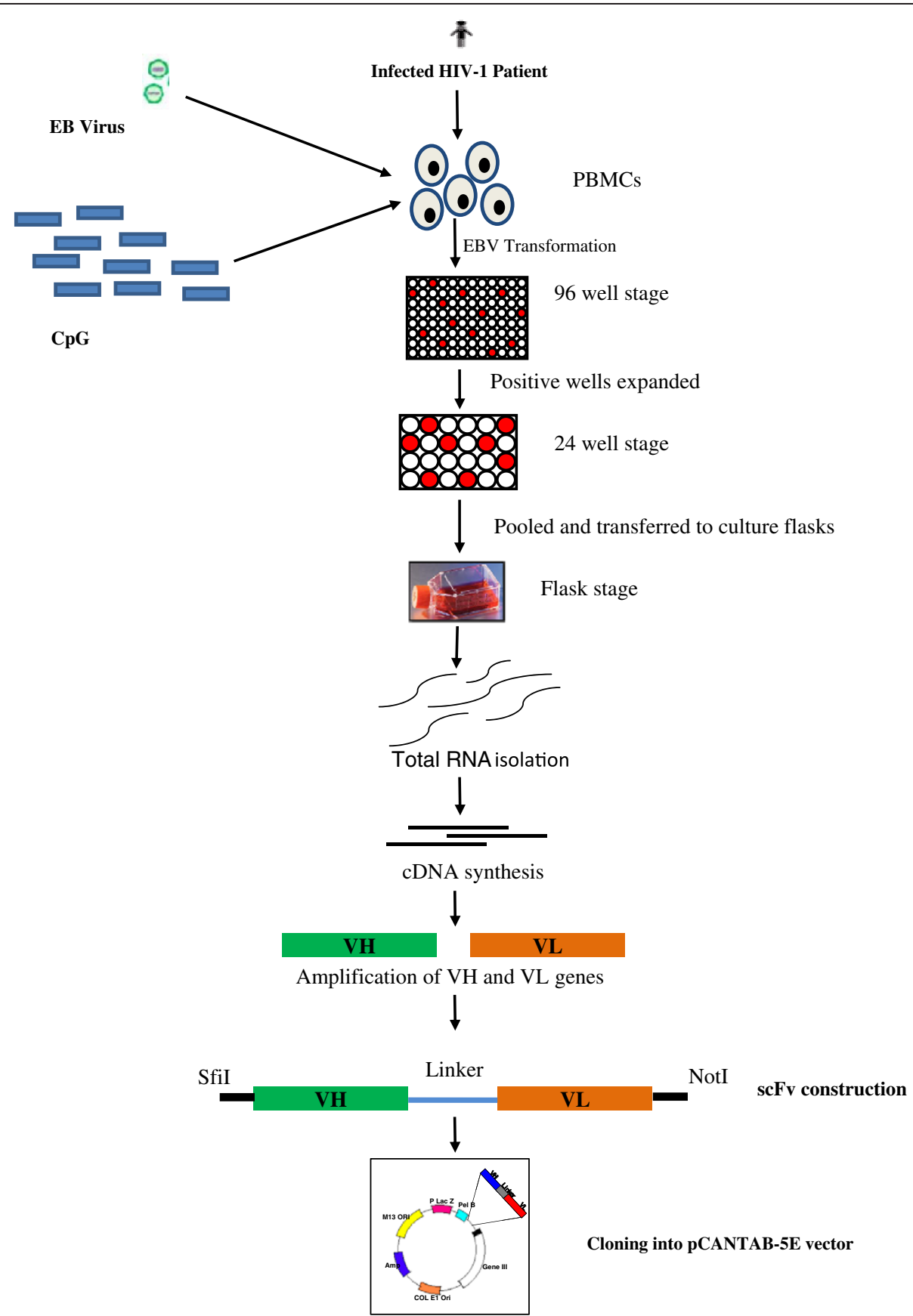

Figure 2 Schematic overview of the strategy used for construction of antigen specific phage library. The peripheral blood mononuclear cells (PBMCS) were isolated from an antiretroviral drug naïve patient (\#254) whose plasma exhibited neutralizing activity against a panel of viruses and also displayed cross clade reactive anti-V3 antibody binding potential. PBMCs were subjected to EBV transformation in 96 well culture plate, wells showing high level of anti-V3 antibodies were selected and expanded to 24 well stage and then to six well stage . The wells showing high titre of anti-V3 Abs were pooled together and cultured in T25 flask. Total RNA was isolated from these antigen specific enriched B cells and cDNA was synthesised. Heavy and light chains were amplified and scFvs were constructed and cloned into a pCANTAB-5E phagemid vector. scFv phage library of 7000 clones was constructed.

genes except for IGHD1. Diversity of the VL paratope was also limited with IGKV1, IGKV2 and IGKV3 being most represented, except for one occurrence of IGKV7 (Table 3).
Selection of scFvs against the V3 region of HIV-1

As the size of the library was very small, one round of biopanning was done against the V3 $\mathrm{C}$ and V3 $\mathrm{B}$ peptides. Forty clones were randomly selected and checked for 
Table 2 Screening of EBV transformed PBMCs isolated from a drug naïve HIV-1 infected patient (\# 254) for V3 reactivity

\footnotetext{
${ }^{1}$ Total number of PBMCs isolated (millions) from

HIV-1 infected patient \# 254

${ }^{2}$ Number of cells plated per well

4.8

100000

${ }^{3}$ Total number of wells plated with the cells and EBV transformed in 96 well culture plate

${ }^{4}$ Number of wells successfully EBV transformed

${ }^{5}$ Number of wells secreting anti-V3 Abs (OD>2) in 96 well stage(first screening)

${ }^{6}$ Number of wells secreting anti-V3 Abs (OD>0.6) in 24 well stage(second screening)

${ }^{7} \mathrm{OD}$ at flask stage(Final screening) (OD>1.0)

${ }^{1}$ PBMCs were isolated from a HIV positive drug naïve patient sample (\# 254). A total of 4.8 million PBMCs were isolated.

${ }^{2}$ Number of cells plated per well was 100000 .

${ }^{3}$ Forty eight wells were subjected to EBV transformation.

${ }^{4}$ All the 48 wells were successfully transformed (transformation efficiency $100 \%)$.

${ }^{5} 7 / 48$ (approx 14.6\%) wells showed positive binding (OD $>2$ ) with V3 peptide and expanded to 24 well stage.

${ }^{6} 5 / 7$ (approx $71 \%$ ) wells showed positive binding (OD $\left.>0.6\right)$ with V3 peptide and pooled down and grown in T-25 flask.

${ }^{7}$ Final screening for anti-V3 antibody binding reactivity was done at flask stage (OD>1.0).
}

their binding, of which 15 showed positivity in phage ELISA with both the peptides (Figure 5). Four clones were randomly selected for ELISA with purified phage. The binding specificity of these anti-V3 scFvs was checked with phage from the 24 well plate and PEG precipitated purified phage. The 24 well ELISA and pure phage ELISA binding assays showed similar results. Three clones exhibited almost similar binding in both the formats of ELISA while one clone had lower binding reactivity in pure phage ELISA although it was not completely lost (data not shown). DNA fingerprinting analysis using BstN1 followed by sequencing revealed that $13 / 15$ clones were distinct (Table 4). All the distinct 13 anti -V3 scFvs that were finally selected, showed cross-reactivity against both the V3 peptides and did not show any reactivity against other unrelated peptides. One round of biopanning was found to be sufficient to get V3 positive scFv clones with diversity.

\section{Soluble scFv production}

The antigen binding clones showing positivity/binding in the phage ELISA were further processed for soluble scFv expression by induction with $1 \mathrm{mM}$ IPTG [28]. After induction, the periplasmic lysate, inclusion bodies, culture supernatant and whole cell extract were prepared and analysed for $\mathrm{scFv}$ expression on a $12 \%$ reducing SDSPAGE. The scFv fusion protein was found to be expressed in the cell lysate, culture supernatant, periplasmic extract, with highest expression in the inclusion bodies. $\mathrm{scFv}$
A

B $1222 \quad 3 \quad 3$ M 44455566

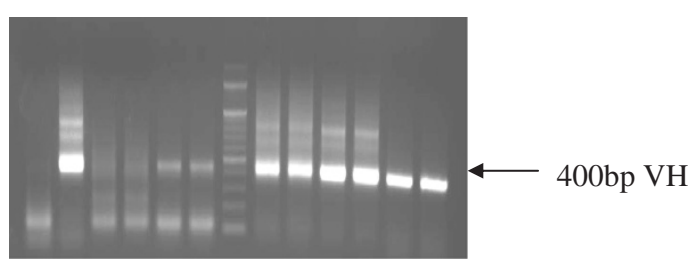

B

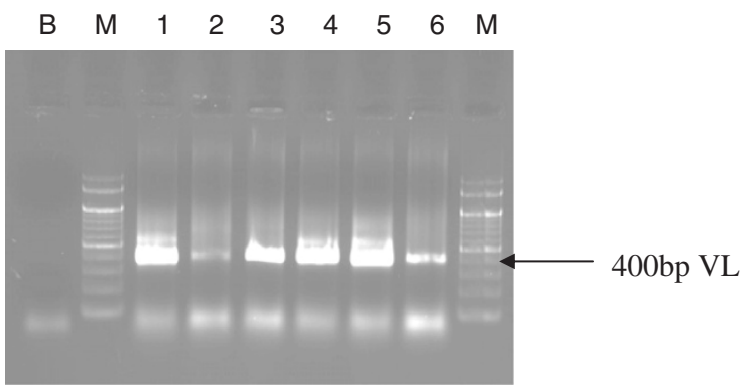

C

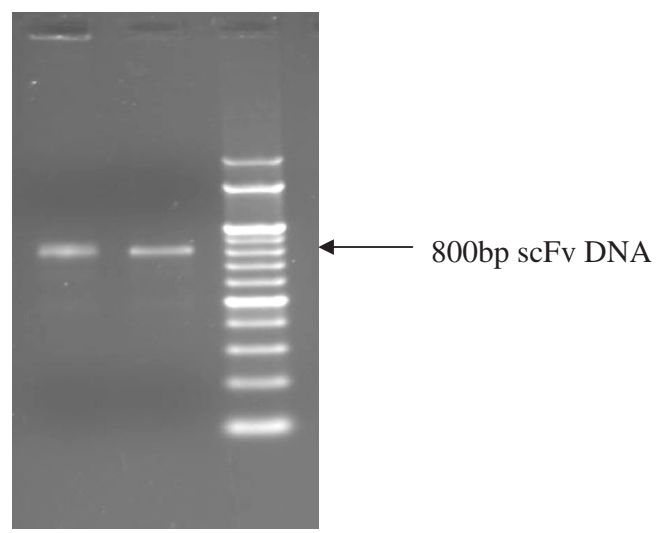

Figure 3 Amplification of VH and VL genes. A. Agarose gel electrophoresis (1\%) of PCR amplified products of heavy chain $(\mathrm{VH})$ genes using all combinations of the 24 primers. Lane B, PCR blank (negative control); Lane M, DNA marker (100 bp ladder); Lanes 1-6 is with VH1-6 with reverse primers (R1, R2, R3 and R4). Samples that were loaded in duplicates are indicated as numbers 2, 2 and 3, 3 so on. B. Agarose gel electrophoresis (1\%) of PCR amplified products of light chain (VL) genes. Lane B, PCR blank negative control; Lane M, DNA marker (100 bp ladder); Lane 1-6 is with VKL1-6 with reverse primers. C. Pull through PCR for scFv construction, Agarose gel electrophoresis (1\%) of PCR amplified products of sCFvs constructed by pull through PCR. Lane M, DNA ladder (100 bp); Lanes 1 \& 2 are amplified scFv DNA products.

expression was also observed in the uninduced culture (Figure 6).

\section{Purification of E-tagged scFv and Western blot analysis}

The scFvs were expressed in E. coli HB2151 cells by inducing for 6 to $8 \mathrm{~h}$ with $1 \mathrm{mM}$ IPTG at $24^{\circ} \mathrm{C}$. The 


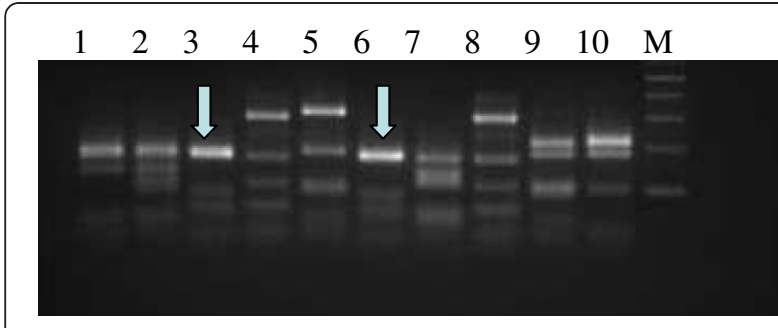

Figure 4 DNA fingerprinting analysis of scFv clones. Ten $\mathrm{scFv}$ gene fragments were amplified by PCR and digested with BstN1 at $60^{\circ} \mathrm{C}$ for 3 hours. Restriction pattern was analysed on $2 \%$ agarose gel. Arrows indicate that clones 3 and 6 exhibit identical DNA fingerprinting pattern. Lane M, DNA ladder (100 bp). antibody fragments were purified from the periplasmic extract and the purified product was analysed by SDSPAGE. The scFv protein of $32 \mathrm{kDa}$ was expressed in different elute fractions E1 to E5 (Figure 7C) and protein samples were concentrated using ultrafiltration columns (Ambion) over a $10 \mathrm{kDa}$ cut off.

Expression of the $\mathrm{scFv}$ fusion protein $(32 \mathrm{kD})$ in the periplasmic extract was confirmed by Western blotting. The cell lysate of HB2151 was used as a negative control (Figure 7D).

Validation of antigen binding of the scFv clones

The functional activity of the newly generated clones $3 \mathrm{E} 6 \mathrm{~B}$ and $3 \mathrm{E} 7 \mathrm{~B}$ was assessed by their binding to the V3

Table 3 Diversity of scFvs in unselected phage library

\begin{tabular}{|c|c|c|c|c|c|}
\hline \multirow[b]{2}{*}{ scFv } & \multicolumn{3}{|l|}{ VH } & \multicolumn{2}{|l|}{ VL } \\
\hline & v & D & $J$ & V & $J$ \\
\hline 1 & IGHV1-18*01 & IGHD6-19*01 & IGHJ3*02 & IGKV3-NL5*01 & IGKJ2*02 \\
\hline 2 & IGHV4-b*02 & IGHD3-10*02 & IGHJ4*02 & IGKV3-20*01 & IGKJ2*01 \\
\hline 3 & IGHV4-b*02 & IGHD3-3*01 & IGHJ6*02 & IGKV1D-12*02 & IGKJ3*01 \\
\hline 4 & IGHV4-b*02 & IGHD3-10*02 & IGHJ4*02 & IGKV2D-28*01 & IGKJ2*01 \\
\hline 5 & IGHV4-b*02 & IGHD3-10*02 & IGHJ4*02 & IGKV3-11*01 & IGKJ1*01 \\
\hline 6 & IGHV4-b*02 & IGHD3-10*02 & IGHJ4*02 & IGKV3-20*01 & IGKJ4*01 \\
\hline 7 & IGHV4-b*02 & IGHD3-10*02 & IGHJ4*02 & IGKV2-30*01 & IGKJ4*01 \\
\hline 8 & IGHV4-b*02 & IGHD4-4*01 & IGHJ5*02 & IGKV2D-28*01 & IGKJ2*01 \\
\hline 9 & IGHV4-b*02 & IGHD6-6*01 & IGHJ3P*01 & IGHV1/OR15-2*02 & IGHD5-5*01 \\
\hline 10 & IGHV4-b*02 & IGHD5-24*01 & IGHJ4*02 & IGKV3-20*01 & IGKJ2*01 \\
\hline 11 & IGHV4-31*03 & IGHD3-10*02 & IGHJ4*02 & IGKV3-20*01 & IGKJ2*01 \\
\hline 12 & IGHV4-31*03 & IGHD5-5*01 & IGHJ6*03 & IGKV1D-39*01 & IGKJ1*01 \\
\hline 13 & IGHV4-61*02 & IGHD2-8*02 & IGHJ3*02 & IGKV1D-12*02 & IGKJ2*01 \\
\hline 14 & IGHV4-59*08 & IGHD5-24*01 & IGHJ3*02 & IGKV3D-20*01 & IGKJ1*01 \\
\hline 15 & IGHV5-51*01 & IGHD4-4*01 & IGHJ6*01 & $I G K V 2 D-28 * 01$ & $I G K J 2 * 01$ \\
\hline 16 & IGHV5-51*01 & IGHD4-4*01 & $I G H J 6 * 01$ & IGKV2D-28*01 & $I G K J 2 * 01$ \\
\hline 17 & IGHV5-51*01 & IGHD4-4*01 & IGHJ5*02 & IGKV2D-28*01 & IGKJ2*01 \\
\hline 18 & IGHV5-51*01 & IGHD4-4*01 & IGHJ5*02 & IGKV2D-28*01 & $I G K J 2 * 01$ \\
\hline 19 & IGHV5-51*01 & IGHD4-4*01 & IGHJ5*02 & IGKV2D-28*01 & $I G K J 2 * 01$ \\
\hline 20 & IGHV5-51*01 & IGHD4-4*01 & IGHJ5*02 & IGKV2-30*02 & IGKJ1*01 \\
\hline 21 & IGHV5-51*01 & IGHD4-4*01 & IGHJ5*02 & IGKV1D-12*02 & IGKJ3*01 \\
\hline 22 & IGHV5-51*01 & IGHD4-4*01 & IGHJ5*02 & IGKV1D-12*02 & $I G K J 3 * 01$ \\
\hline 23 & IGHV5-51*01 & IGHD4-4*01 & IGHJ5*02 & IGKV1D-12*02 & $I G K J 3 * 01$ \\
\hline 24 & IGHV5-51*01 & IGHD4-4*01 & $I G H J 5 * 02$ & IGKV1D-12*02 & $I G K J 3 * 01$ \\
\hline 25 & IGHV5-51*01 & IGHD4-4*01 & IGHJ5*02 & IGKV3-20*01 & IGKJ3*01 \\
\hline 26 & IGHV5-51*01 & IGHD4-4*01 & IGHJ5*02 & IGKV3-20*01 & IGKJ1*01 \\
\hline 27 & IGHV5-51*01 & IGHD4-4*01 & IGHJ5*02 & IGKV7-3*01 & IGKJ2*04 \\
\hline 28 & IGHV5-51*01 & IGHD4-4*01 & IGHJ5*02 & IGKV3-11*02 & IGKJ1*01 \\
\hline 29 & IGHV5-51*01 & IGHD4-4*01 & IGHJ5*02 & IGKV3-11*01 & IGKJ1*01 \\
\hline
\end{tabular}

Identical sequences of clones 15 and 16, 18 and 19,22, 23 and 24 are shown in italic. 


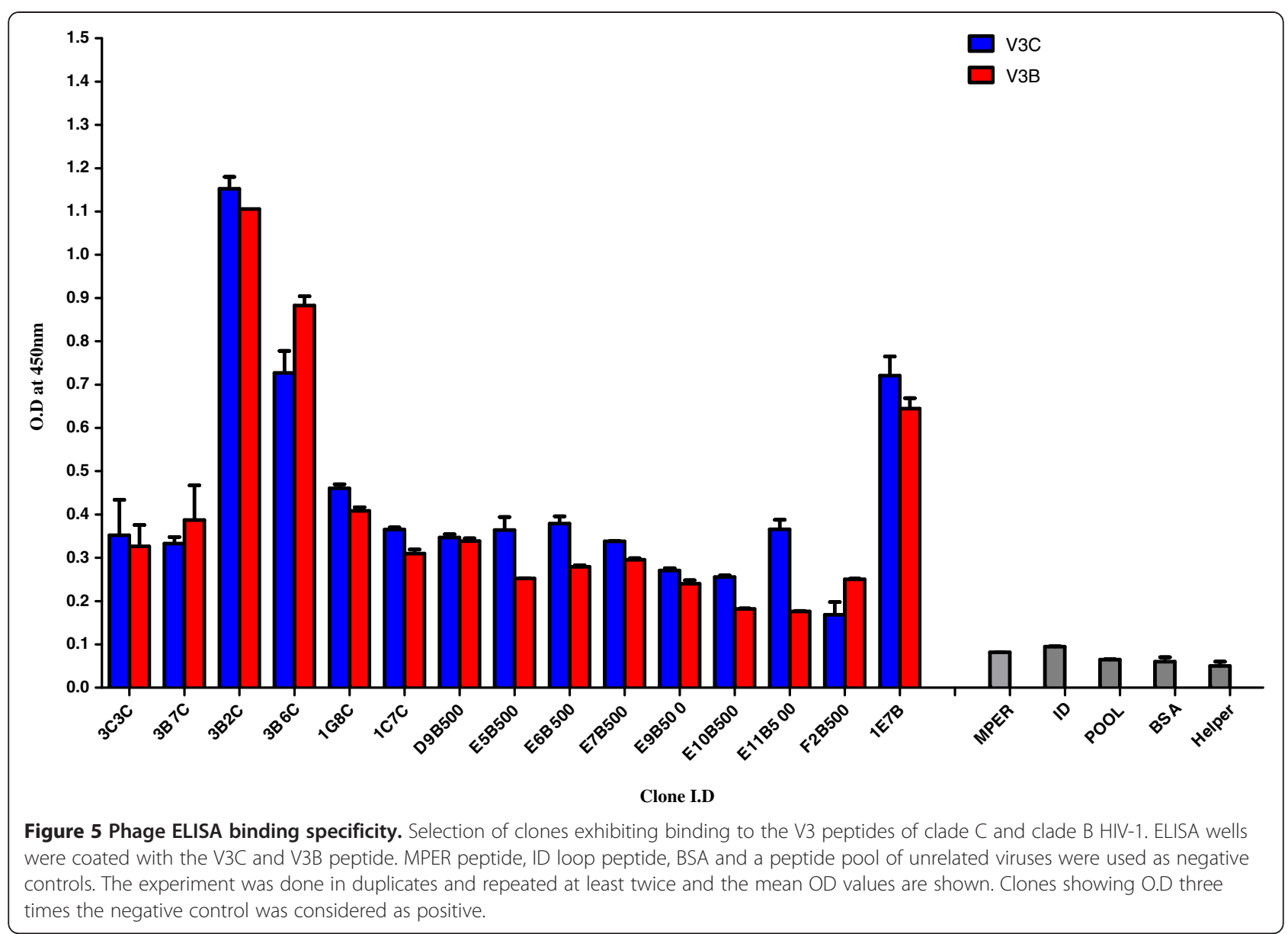

peptides of Clade $\mathrm{C}$ and $\mathrm{B}$ in ELISA. Both the scFvs showed specific binding to the V3 peptides (Figure 8). In addition, these scFvs did not bind to other unrelated peptides like MPER and ID loop of HIV, peptide pool (unrelated viruses) and BSA.
Neutralization potential of anti-V3 scFvs

The purified scFvs were tested for the viral neutralization potential against a panel of pseudoviruses from clades A, B and C HIV-1 viruses (Table 5). Clone 3E6B was able to neutralize $1 / 1$ clade $A, 2 / 2$ clade $B$ and $1 / 3$

Table 4 Gene usage of anti-V3 scFvs

\begin{tabular}{|c|c|c|c|c|c|}
\hline \multirow[t]{2}{*}{ scFv } & \multicolumn{3}{|l|}{ VH } & \multicolumn{2}{|l|}{ VL } \\
\hline & v & D & $J$ & v & $J$ \\
\hline 1D5C & IGHV3-23*04 & IGHD3-10*01 & IGHJ3*02 & IGKV3-20*01 & IGKJ1*01 \\
\hline 1E7B & IGHV4-31*03 & IGHD5-24*01 & IGHJ6*03 & IGKV3-20*01 & IGKJ2*01 \\
\hline $1 \mathrm{G} 8 \mathrm{C}$ & IGHV5-51*01 & IGHD4-11*01 & IGHJ5*02 & IGKV2-28*01 & IGKJ2*01 \\
\hline $3 \mathrm{~B} 2 \mathrm{C}$ & IGHV5-51*01 & IGHD4-11*01 & IGHJ5*02 & IGKV1-5*03 & IGKJ4*01 \\
\hline $3 B 6 C$ & IGHV4-b*02 & IGHD3-10*02 & IGHJ4*02 & IGKV1-39*01 & IGKJ2*02 \\
\hline $3 B 7 C$ & IGHV4-b*02 & IGHD3-10*02 & IGHJ1*01 & IGKV3-20*01 & IGKJ4*01 \\
\hline $3 C 3 C$ & IGHV5-51*01 & IGHD4-11*01 & $I G H J 5 * 02$ & IGKV3-20*01 & $I G K J 1 * 01$ \\
\hline $3 \mathrm{E} 6 \mathrm{C}$ & IGHV4-59*08 & IGHD3-10*02 & IGHJ1*01 & IGKV1-12*02 & IGKJ3*01 \\
\hline $3 \mathrm{E} 6 \mathrm{~B}$ & IGHV4-b*02 & IGHD3-10*02 & IGHJ4*02 & IGKV1-39*01 & IGKJ4*01 \\
\hline $3 E 7 B$ & IGHV5-51*01 & IGHD4-11*01 & IGHJ5*02 & IGKV3-20*01 & $I G K J 1 * 01$ \\
\hline
\end{tabular}

This table shows the gene usage of the ten anti-V3 scFvs. Nine out of the ten sequences are distinct. Clones 3 C $3 \mathrm{C}$ and $3 \mathrm{E} 7 \mathrm{~B}$ show similar gene usage which are shown in italic. 


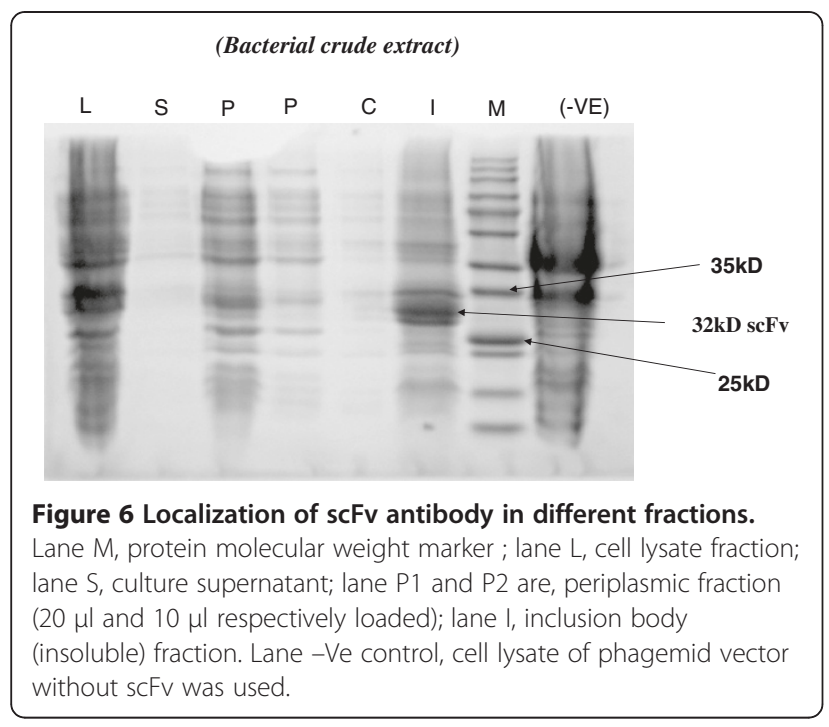

clade $\mathrm{C}$ viruses. The other clone 3E7B was only able to neutralize 1 clade $C$ virus.

\section{Discussion}

We have demonstrated in this study a strategy that successfully yielded recombinant human scFvs against the V3 region of HIV-1 using a pool of antigen selected EBV transformed B lymphocytes and phage display technology. The use of preselected B cells producing anti- V3 antibodies for phage scFv library construction proved to be an efficient strategy for the isolation of V3 specific clones. Moreover, this approach has prevented any loss of unstable or slowly growing clones which may have useful and unique binding specificities (that often occurs during cloning and propagation).

Stringency during the initial stages helps in elimination of most of the false positive clones. Beginning with the 96 well stage and up to the final screening of the cells in the T25 flask, we selected only those wells with high V3 binding reactivity for further expansion and finally for the phage library construction. By this approach, we obtained a phage library with an adequate number of V3 binding clones. Amplification of the heavy chain gene showed that the VH1, VH4, VH5 and VH6 were preferentially more expressed than the $\mathrm{VH} 2$ and $\mathrm{VH} 3$ and corroborated with the previous reports [29] that anti-V3 antibodies more preferentially exhibit the above gene usages. It is well established that in HIV-1 infection, VH3 genes are less preferentially used [30,31]. From the sequencing data, we observed that twenty nine randomly selected clones from the EBV transformed cells library exhibited the VH4 and VH5 gene usage suggesting that our library may be biased towards antigen specificity. In healthy individuals, VH3 genes are most frequently used and VH5 is used only by a low percentage of antibodies (http:imgt.cines.fr). The light chain did not show any preferential gene usage and all the light chains were successfully amplified.

A

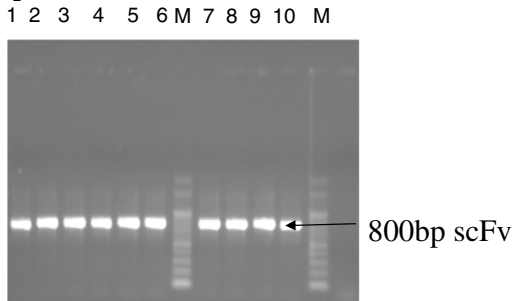

C

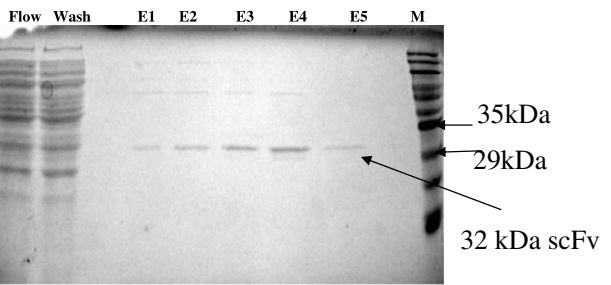

B

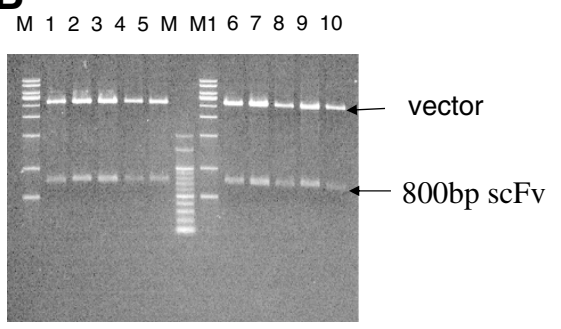

D

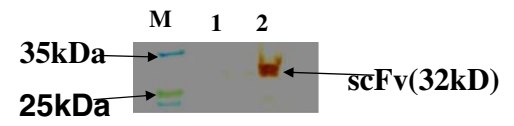

Figure 7 Analysis of scFv clones by agarose gel electrophoresis (1\%) and purification of scFvs. A. Agarose gel analysis of colony PCR of 10 randomly selected clones from library before panning. B. Agarose gel analysis of Sfil and Notl digested plasmid of 10 randomly selected clones from library before panning. Lane M, 100 bp marker; Lane M1 1kb ladder; Lane 1-10 are plasmid DNA from ten different clones. C. SDS- PAGE (12 \%) of purified scFv Lane M, protein marker; Lane E1 to E5, different eluted fractions of purified scFv. Arrow indicates the 32kDa band of scFv in E1 to E5 lanes. D. Western blot analysis of purified scFv, pCANTAB-5E vector periplasmic extract was used as a negative control. Lane M, prestained molecular weight marker. 


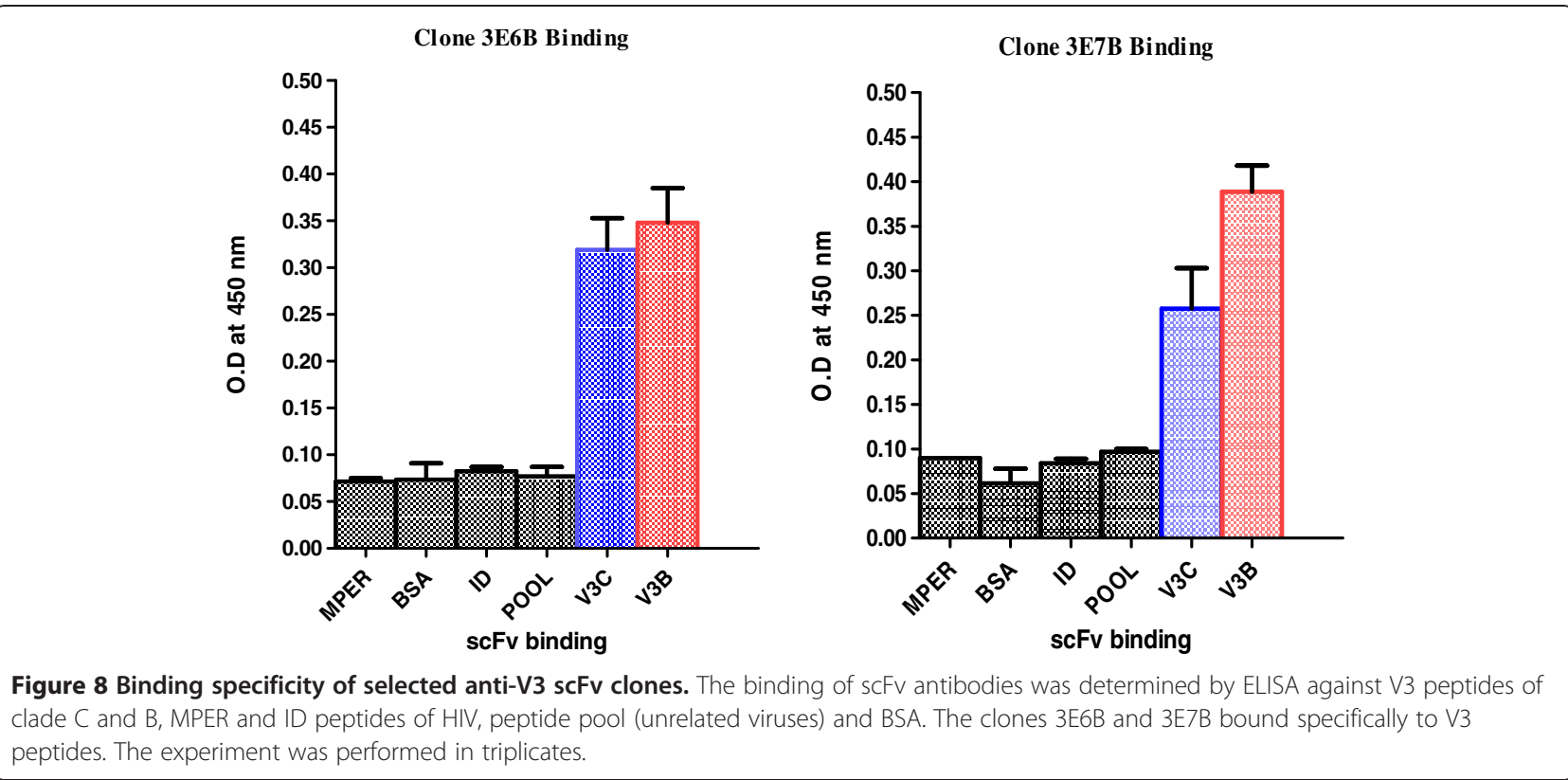

As heavy chain amplification was biased towards the expression of a set of heavy chain genes, to avoid predominant expression of one subset of genes in the phage library, we took an equal concentration of all the heavy chain genes which in turn increased the chances of the new combinations that are not expressed in natural infection. Successful isolation of positive clones with higher affinity and specificity is possible when a library is more diverse and has less number of clones with incomplete scFvs sequences [15,32]. If phage carrying incomplete scFvs are more in number, they overwhelm the library after multi-step panning thereby the presence of the full size insert will decrease, this being a common problem with phage libraries. Interestingly, our library

Table 5 Neutralization potential of anti-V3 scFvs against a panel of pseudoviruses and primary isolates

\begin{tabular}{llllll}
\hline Virus & Clade & 3E6B & 3E7B & scFv (HepB) & 1418 \\
\hline 92RW & A & 45 & $>100$ & $>150$ & $>150$ \\
SF162 & B & 115 & $>100$ & $>150$ & $>150$ \\
QZ4589 & B & 50 & $>100$ & $>150$ & $>150$ \\
AlIMS 261 & C & 110 & 45 & $>150$ & $>150$ \\
Du 422 & C & $>150$ & $>100$ & $>150$ & $>150$ \\
ZM 53 & C & $>150$ & $>100$ & $>150$ & $>150$ \\
\hline
\end{tabular}

The cross neutralizing activities of two anti-V3 scFv clones against a panel of subtype- $A, B, C$ viruses that are listed on the left. The numerical values in the table represent the concentration $(\mu \mathrm{g} / \mathrm{ml})$ of scFvs at which $50 \%$ neutralization titers (IC50) was reached. AllMS 261 is the primary isolate generated in our lab from a HIV-1 clade C infected patient. scFv (HepB) is an scFv against the Hepatitis B surface antigen (negative control) and 1418 is human antibody to parvovirus (negative control). Each experiment was performed at least two independent times. exhibited 90\% diversity of clones and 100\% clones had complete scFvs (Figure 7A,B), this might be because of the optimum incubation time (30-40 min) maintained during the transformation process that reduced the chances of repetition of clones. In addition, the combination of the Sfi1- NotI site containing pCANTAB-5E vector that we used in the library construction may have reduced or eliminated the chances of getting incomplete $\mathrm{scFv}$ sequences because these restriction enzyme sites are rarely present in the scFv DNA sequence [15,33]. Furthermore, none of our clones had internal Sfi1- NotI sites.

Stringency in the biopanning also reduces the number of false positive clones. Initially, phage were allowed to bind to the plastic plate, next, to coated milk, followed by BSA and finally onto a pool of coated unrelated antigens in the plates. This stringency reduced the number of nonspecific phage binders and made the screening process more convenient and specific.

Kempf et al., using a similar strategy of EBV transformation, constructed a Fab library of $10^{7}$ clones from which they isolated three Fabs after one round of biopanning. Their scoring of positive clones however was less, probably because they selected cells positive for gp120 binding from the 96 well stage and also included wells that were low binders ( OD>0.1) [20]. We therefore selected only those wells with high V3 binding reactivity $(O D>0.6)$ at all stages for the phage library construction. This reduced the number of false positive clones and enriched the V3 specific cells.

There are several reports on the generation of scFvs from different sources like PBMCs [34,35], bone marrow [36], tonsils [37], hybridomas [38,39], but none of them 
employed EBV transformed antigen specific cells to generate a $\mathrm{scFv}$ phage library.

Generation of phage library from EBV transformed lines after preselection with antigen is very useful for laboratories with limited resources because the antibody production by traditional hybridoma technology costs ranging between $\$ 8000$ to $\$ 12000$ and $80 \%$ of the costs are incurred in the post EBV immortalization steps like fusions and cloning. Our strategy does not require the expensive process of electroporation because the cost of cuvettes and instrument mainly limits the construction of phage libraries with such a large size and diversity; also it eliminates the large number of biopanning rounds followed by cumbersome screening processes. Such small libraries are easy to maintain and can be produced by routinely used calcium chloride mediated transformations.

\section{Conclusions}

We have for the first time, generated anti-V3 human scFvs against clade $\mathrm{CHIV}-1$. By antigen pre-selection, the phage library served as an adequate source of $\mathrm{V} 3$ positive clones. The combination of EBV transformation and selection of immortalized lines that exhibit the desired antigen binding characteristics with phage display technology provides a useful strategy for specific recombinant antibody generation. Our study validated the generation of recombinant libraries as a powerful tool for the generation of diverse recombinant antibodies.

\section{Methods}

\section{Study subject, blood sample collection and processing}

The HIV-1 seropositive patient (\# 254) enrolled for the construction of the anti-V3 scFv phage library was recruited after obtaining written informed consent from the Department of Medicine, AIIMS, New Delhi. The study was approved by the institute ethics committee. Whole blood was collected in EDTA vaccutainers. The plasma was separated from whole blood, aliquoted and stored at $-70^{\circ} \mathrm{C}$ until tested. The peripheral blood mononuclear cells (PBMCs) were separated by phycoll hypaque centrifugation and processed immediately for EBV transformation.

The plasma sample of the patient \# 254 was previously tested and found to exhibit good neutralization potential against a diverse panel of viruses (Table 1). It was also tested for the presence of binding anti-V3 antibodies and the data is shown in Figure 1.

\section{Screening of the patient plasma (\#254) for cross reactive neutralizing antibodies}

The neutralization efficiency of the plasma \#254was tested against a standard panel of pseudoviruses of clades A, B and C obtained from the NIH AIDS Research and Reference Reagent Program, by TZM-bl assay [40]. The standard panel of pseudoviruses has been categorized from tier 1 to tier 3, based on the decreasing order of susceptibility to neutralization by the known monoclonal antibodies [41]. The neutralization assay was carried out in 96-well tissue culture plates. Briefly, $50 \mu \mathrm{l}$ of the heat inactivated plasma/purified $\mathrm{scFv}$, at different dilutions in duplicate, was added to 200 TCID 50 of the virus and incubated for $1 \mathrm{~h}$. A cell control well containing culture media only and a virus control well containing both the culture media and the virus were tested in parallel. The rest of the procedure is the same as described for calculating TCID 50. The scFv (HepB), an scFv against the Hepatitis B surface antigen [42] and 1418, a human antibody to parvovirus B19 protein, were used as negative controls. For all dilutions of test plasma, the percent neutralization was calculated based on the relative luminescence units (RLU) in the presence of plasma divided by the virus control. The cell control value was subtracted from the plasma RLU value as the background cutoff. The $50 \%$ neutralization titer (ID50 titer) was determined for the plasma sample \#254 against each virus by plotting percentage neutralization against the dilution of the plasma tested. A non-linear regression straight line was drawn by the method of least squares, and the reciprocal ID50 titers were extrapolated. The experiments were performed in duplicate and repeated at least twice and the mean ID50 titers were calculated.

Quantitation of the levels of anti-V3 Abs by Peptide ELISA The anti-V3 Antibody content in the HIV-1 seropositive plasma sample \#254 and in the supernatants of the EBV transformed PBMCs in culture at different stages was determined using V3 peptide ELISA. Thirty five mer peptides of V3C (CTRPNNNTRKSIRIGPGQTFYATGDI IGDIRQAHC) and V3B (CTRPNNNTRKSIHIGPGRAFY TTGEIIGDIRQAHC) were synthesised (Sigma Aldrich, USA), based on the consensus V3 sequences. The V3 peptides $(1 \mu \mathrm{g} / \mathrm{ml})$ were coated onto 96 well Nunc-Immuno plates (Nunc: Cat\# 439454) using antigen coating buffer (150 mM Na $2 \mathrm{CO}_{3}, 350 \mathrm{mM} \mathrm{NaHCO} 3,30 \mathrm{mM} \mathrm{NaN}, \mathrm{pH}$ 9.6) at $4^{\circ} \mathrm{C}$ overnight. Plates were washed using phosphate buffered saline with $0.1 \%$ Tween-20 (0.1\% PBST) thrice using a plate washer. Plates were then blocked with 100 $\mu \mathrm{l}$ of $15 \%$ fetal calf serum and incubated at $37^{\circ} \mathrm{C}$ for $1.5 \mathrm{~h}$. Following blocking and washing, heat inactivated plasma $(100 \mu \mathrm{l}$, dilution range $=300-100000)$ or $100 \mu \mathrm{l}$ of supernatants from EBV transformed PBMC cultures was added to each well and incubated for 1 hour at $37^{\circ} \mathrm{C}$. After 3 washings with PBST (0.1\%), the bound V3 specific antibodies were detected by addition of $100 \mu \mathrm{l}$ of alkaline-phosphatase conjugated anti-human IgG Fc (1:2000 in PBST). Immune complexes were revealed with AP-Substrate in DAE buffer and the colorimetric reaction was stopped by the addition of $6 \mathrm{~N} \mathrm{NaOH}$. The 
optical density was read at $405 \mathrm{~nm}$. ID $_{50}$ titers were calculated for the plasma sample against each of the peptide by plotting the absorbance at $405 \mathrm{~nm}$ against the dilutions of the plasma sample tested. A non-linear regression straight line was drawn by the method of Least squares and the $\mathrm{ID}_{50}$ titers were extrapolated.

\section{Epstein -Barr Virus (EBV) induced transformation of PBMCs}

B95 cell line comprises of EBV transformed human lymphoblastoid cells which secrete EBV in the supernatant. EBV transforms human B cells [43]. We obtained the B95 cell line from American Type Cell Culture (Cat. No. VR-1492). B95 cells were grown in T-75 tissue culture flasks, at 100,000 cells $/ \mathrm{ml}$ at $37^{\circ} \mathrm{C}, 5 \% \mathrm{CO}_{2}$, in complete RPMI media. After 10 days, the viral supernatant was centrifuged at $300 \times \mathrm{g}$ and filtered with $0.45 \mu \mathrm{m}$ filters. Peripheral blood mononuclear cells (PBMC) (100,000 cells/well) from the patient \#254 were EBV transformed by mixing with 100 $\mu \mathrm{l}$ of the viral supernatant in a 96-well plate and cultured with a polyclonal B cell activator, CpG $(2 \mu \mathrm{g} / \mathrm{ml})$, which enhanced EBV infection and B cell transformation [44] and $\mathrm{CsA}(0.5 \mu \mathrm{g} / \mathrm{ml})$. The plate was incubated at $37^{\circ} \mathrm{C}$ in a $5 \% \mathrm{CO}_{2}$ incubator overnight. Next day, cells were fed with $100 \mu \mathrm{l}$ of complete medium containing CsA and CpG. Cultures were fed twice per week and half of the culture supernatant was replaced with fresh complete media, $200 \mu \mathrm{l} /$ well (no CsA and CpG).

Screening of B-lymphocytes producing anti-V3 antibodies After two weeks of culturing the B cells in the 96 well plate, we screened for the presence of V3 antibodies by V3 peptide binding ELISA as described above. The positive B cell clones were further expanded to 24 well plates and screened in the $3^{\text {rd }}$ and $4^{\text {th }}$ week; V3 positive clones were transferred to a six well plate, pooled and further expanded to the T-25 flask (Table 2).

\section{Construction of Human anti-V3 scFv phage library}

Total RNA from the V3 specific antibody producing $\mathrm{B}$ cells (from flask stage) was isolated by Trizol reagent (Sigma, USA) and then reverse transcribed to cDNA, using the reverse aid MMuLV reverse transcriptase (Fermentas, USA). A total of $200 \mathrm{ng}$ of RNA was reverse transcribed in a reaction volume of $50 \mu \mathrm{l}$ containing, 10ng of random hexamer, $20 \mu \mathrm{M}$ oligo-dT, $1.5 \mu \mathrm{l}$ of RNase inhibitor $(40 \mathrm{U} / \mu \mathrm{l})$, all dissolved in $1 \mathrm{X} \mathrm{RT}$ buffer. The RNA was heated to $65^{\circ} \mathrm{C}$ for $5 \mathrm{~min}$ and then immediately chilled on ice for at least five minutes. Following the addition of the reaction mixture, the tube was incubated at $42^{\circ} \mathrm{C}$ for $60 \mathrm{~min}$, at $70^{\circ} \mathrm{C}$ for $5 \mathrm{~min}$ and quickly chilled on ice and stored in $-20^{\circ} \mathrm{C}$. Heavy chain variable region genes were amplified using a total of 24 combinations (6 forward primers and 4 reverse primers representing all human immunoglobulin subfamilies) and for light chain kappa, a total of 30 combinations were used ( 6 forward primers and 5 reverse primers) as described previously [15]. A total of 54 independent reactions were performed to generate the variable regions of heavy and light chains. The heavy chain $5^{\prime}$ primers included a SfiI site and the light chain $3^{\prime}$ primer included a NotI site. Light chain $5^{\prime}$ primer included part of the linker region $\left(\mathrm{Gly}_{4} \mathrm{Ser}\right)_{3}$ and this was compatible with the heavy chain $3^{\prime}$ primer. Each variable heavy region was amplified using Hot start Taq DNA polymerase (Fermentas) in a PCR reaction of $50 \mu \mathrm{l}$ containing $2.5 \mu \mathrm{l}$ cDNA, primers $1 \mu \mathrm{l}$ (10 pmole each) both forward and reverse. PCR reaction was performed for 34 cycles $\left(94^{\circ} \mathrm{C}\right.$ for $3 \mathrm{~min}$ initial denaturation, $94^{\circ} \mathrm{C}$ for $1 \mathrm{~min}$, annealing at $63^{\circ} \mathrm{C}$ for $1 \mathrm{~min}$, extension at $72^{\circ} \mathrm{C}$ for $2 \mathrm{~min}$ ) using eppendorf Master Cycler. Light chain variable region were amplified with the similar protocol except the annealing temperature used was $57^{\circ} \mathrm{C}$. Each variable region gene was purified from the agarose gel using gel extraction kit (Qiagen, Germany). An equimolar mixture of pooled heavy and light chain DNA was used in the second round assembly PCR. The assembly PCR reaction was cycled 20 times $\left(94^{\circ} \mathrm{C}\right.$ for $1 \mathrm{~min}, 94^{\circ} \mathrm{C}$ for 45 $\mathrm{sec}, 62^{\circ} \mathrm{C}$ for $50 \mathrm{sec}, 72^{\circ} \mathrm{C}$ for $2 \mathrm{~min}$ ) the assembly reaction was performed using Pfu DNA polymerase and without primers. Full length scFvs were amplified using a pull through PCR reaction using Taq DNA polymerase and the following primers PTfw $5^{\prime} \mathrm{CCT}$ TTC TAT GCG GCC CAG CCG GCC ATG GCC $3^{\prime}$ and PTrv $5^{\prime}$ CAG TCA TTC TCG ACT TGC GGC CGC ACG $3^{\prime}\left(94^{\circ} \mathrm{C}\right.$ for $1 \mathrm{~min}$, annealing at $62^{\circ} \mathrm{C}$ for $1 \mathrm{~min}$, extension at $72^{\circ} \mathrm{C}$ for $1 \mathrm{~min}$ and final extension at $72^{\circ} \mathrm{C}$ for $5 \mathrm{~min}$ ). The scFvs were agarose gel purified using gel extraction kit (Qiagen, Germany).

\section{Cloning of anti-V3 scFv into pCANTAB -5E vector}

The scFv DNA fragments and pCANTAB-5E vector were digested with NotI /SfiI (New England Biolabs, USA) respectively. The digested $\mathrm{scFv}$ DNA fragments and pCANTAB-5E vector were gel purified using gel extraction kit (Qiagen, Germany). The scFv DNA was ligated into vector at a 3:1 molar ratio using T4 DNA ligase (New England Biolabs, USA). The ligated DNA was transformed into chemically competent cells of E.coli TG1 and placed on ice for $1 \mathrm{~h}$ followed by heat shock treatment for 90 seconds and chilled on ice for $5 \mathrm{~min}$. Next, $800 \mu \mathrm{l}$ of $2 \mathrm{XYT}$ media was added and incubated in a rotating shaker at $200 \mathrm{rpm}$ for 40 min. The transformed cells were plated on to $2 \mathrm{XYT}$ medium agar plates containing ampicillin $(50 \mathrm{mg} / \mathrm{ml})$ and $2 \%$ glucose, and incubated overnight at $37^{\circ} \mathrm{C}$. The following day, colonies were scraped into $1 \mathrm{ml}$ of $2 \mathrm{XYT}$ medium with $20 \%$ glycerol and stored at $-70^{\circ} \mathrm{C}$. Sequence of the assembled $\mathrm{scFv}$ was confirmed by an automated ABI prism sequencer using gene specific primers. 


\section{Panning of the scFv phage library}

The phage were rescued by infection with helper phage (M13-KO7), followed by precipitation with $\mathrm{PEG} / \mathrm{NaCl}$, resuspension in PBS and titration for the determination of phage concentration. The phage were then subjected to a single round of enrichment by bio-panning.

The panning procedure was carried out in Immuno 96 microwell plates. Plates were coated with $100 \mu \mathrm{l}$ of V3 peptide $1 \mu \mathrm{g} / \mathrm{ml}$ in $0.1 \mathrm{M} \mathrm{NaHCO}_{3}$ ( $\mathrm{pH}$ 8.6) overnight at $4^{\circ} \mathrm{C}$. A phage library of $10^{12}$ phage was incubated for $1 \mathrm{~h}$ in milk coated wells to remove the non-specific binders. After one hour, unbound phage were transferred to the peptide coated wells for $30 \mathrm{~min}$ at RT. The unbound phage was eliminated by washing 10-15 times with PBS containing $0.1 \%$ Tween 20 . The bound phage was eluted with $0.2 \mathrm{M}$ glycine $\mathrm{pH} 2.2$ for $10 \mathrm{~min}$ at RT. The eluted phage were neutralized with $1 \mathrm{M}$ Tris $\mathrm{HCl}$ pH 9.2 and immediately infected onto TG1 (OD 0.4 to .5) for 30 min at $37^{\circ} \mathrm{C}$ and for $30 \mathrm{~min}$ with shaking at $37^{\circ} \mathrm{C}$. Cells were spun down and plated on 2XTY agar containing ampicillin $(50 \mathrm{mg} / \mathrm{ml})$ and $2 \%$ glucose. Individual colonies were picked and grown in 96 well sterile culture plates (Corning) and a glycerol stock was made and stored at $-70^{\circ} \mathrm{C}$.

\section{Phage Rescue (24 well plate)}

Individual colonies were grown in $1 \mathrm{ml} 2 \mathrm{XYT}$ broth containing ampicillin and $2 \%$ glucose overnight with shaking at $37^{\circ} \mathrm{C}$ at $160 \mathrm{rpm}$. A small inoculum was transferred to $1 \mathrm{ml} 2 \mathrm{XYT}$ broth containing ampicillin $(50 \mathrm{mg} / \mathrm{ml})$ and $2 \%$ glucose at $37^{\circ} \mathrm{C}$ with shaking at $200 \mathrm{rpm}$ till the OD reached 0.4 to 0.5 . Helper phage were added and the plate was incubated at $37^{\circ} \mathrm{C}$ without shaking and then for $30 \mathrm{~min}$ with shaking at $180 \mathrm{rpm}$ at $37^{\circ} \mathrm{C}$. The cells were spun down at $1500 \times \mathrm{g}$, the supernatant was discarded and pellet was washed with $2 \mathrm{XYT}$ broth. The pellet was then resuspended in 2XYT broth containing ampicillin $(50 \mathrm{mg} / \mathrm{ml})$ and kanamycin $(100 \mathrm{mg} / \mathrm{ml})$ (no glucose) with shaking at $160 \mathrm{rpm}$ at $30^{\circ} \mathrm{C}$ for $16-18 \mathrm{~h}$. It was then centrifuged at $6000 \times \mathrm{g}$ and the supernatant was collected and stored at $4^{\circ} \mathrm{C}$ and an aliquot was tested in the phage ELISA.

\section{Phage ELISA}

The ELISA plates were coated with $100 \mu \mathrm{l}$ of V3 peptide $(1 \mu \mathrm{g} / \mathrm{ml})$ in $0.1 \mathrm{M} \mathrm{NaHCO}_{3}(\mathrm{pH}$ 8.6) and incubated overnight at $4^{\circ} \mathrm{C}$. The plates were washed once with $1 \mathrm{X}$ PBS and blocked with $4 \%$ non-fat milk (Titan Biotech, India) for $2 \mathrm{~h}$ at $37^{\circ} \mathrm{C}$. The plates were then washed three times with $1 \mathrm{X}$ PBS. Phage supernatant $(100 \mu \mathrm{l})$ was added to each well and incubated for $1 \mathrm{~h}$ at RT. Phage supernatant was discarded and the plates were washed four times with PBST(0.1\%). $100 \mu \mathrm{l}$ of anti M13 antibody (diluted 1:2000) was added (Sigma) and incubated for $1 \mathrm{~h}$ at $\mathrm{RT}$. The plates were washed four times with PBST (0.1\%). $100 \mu \mathrm{l}$ of anti rabbit HRP (Jackson) diluted 1:3000 were added and incubated at RT for $1 \mathrm{~h}$. The plates were then washed four times with PBST (0.1\%). $100 \mu \mathrm{l}$ of TMB substrate was added, and the reaction was stopped by adding $8 \mathrm{~N} \mathrm{H}_{2} \mathrm{SO}_{4}$. Absorbance was measured at 450nm.

\section{PEG precipitation of phage (pure phage preparation)}

Individual bacterial colonies were grown in $5 \mathrm{ml} 2 \mathrm{XYT}$ medium containing ampicillin $(50 \mathrm{mg} / \mathrm{ml})$ and $2 \%$ glucose with shaking at $200 \mathrm{rpm}$ at $37^{\circ} \mathrm{C}$ till the O.D reached 0.4 to 0.5 . Next, $1 \mu \mathrm{l}$ of $\mathrm{KO} 7$ helper phage $\left(10^{18}\right)$ was added and incubated at $37^{\circ} \mathrm{C}$ for $30 \mathrm{~min}$ without shaking, followed by $30 \mathrm{~min}$ shaking at $200 \mathrm{rpm}$. The cells were centrifuged at $2500 \times \mathrm{g}$ for $10 \mathrm{~min}$, supernatant was discarded and the pellet was washed again with $2 \mathrm{XYT}$ broth. The pellet was resuspended in $50 \mathrm{ml} 2 \mathrm{XYT}$ broth containing Ampicillin $(50 \mathrm{mg} / \mathrm{ml}$ ) and Kanamycin $(100 \mathrm{mg} / \mathrm{ml})$ (no glucose) at $30^{\circ} \mathrm{C}$ with shaking at $160 \mathrm{rpm}$ for $12-16 \mathrm{~h}$. It was then centrifuged at $10000 \times \mathrm{g}$ for 20 min at $4^{\circ} \mathrm{C}$. The supernatant was transferred to glass bottles and $1 / 4$ volume of $\mathrm{PEG} / \mathrm{NaCl}$ was added and kept on ice for 4 to $6 \mathrm{~h}$ followed by centrifugation at 20000 $\times \mathrm{g}$ for $20 \mathrm{~min}$ at $4^{\circ} \mathrm{C}$. The supernatant was discarded and the pellet was dissolved in sterile and autoclaved $1 \mathrm{X}$ PBS and stored at $4^{\circ} \mathrm{C}$. The transformation unit (TU) was calculated.

\section{DNA sequencing and sequence analysis}

Twenty nine scFvs clones were randomly selected from the unselected library and sequenced by Macrogen (South Korea). The sequences were analysed using immunoglobulin BLAST [45] and V BASE software [46].

\section{DNA fingerprinting of antibody fragments}

The diversity of the $\mathrm{scFv}$ repertoire was analysed by comparing the restriction digestion pattern of scFvs. Ten clones were randomly selected from the primary phage library and the plasmid was isolated. The scFv sequences were amplified using primers PTfw $5^{\prime}$ CCT TTC TAT GCG GCC CAG CCG GCC ATG GCC $3^{\prime}$ and PTrv $5^{\prime}$ CAG TCA TTC TCG ACT TGC GGC CGC ACG $3^{\prime}$ $\left(94^{\circ} \mathrm{C}\right.$ for $1 \mathrm{~min}$, annealing at $62^{\circ} \mathrm{C}$ for $1 \mathrm{~min}$, extension at $72^{\circ} \mathrm{C}$ for $1 \mathrm{~min}$ and final extension at $72^{\circ} \mathrm{C}$ for $5 \mathrm{~min}$ ). The amplified PCR products were digested with a frequent cutter restriction enzyme BstN1 (NEB) and analysed on 2\% agarose gel.

\section{Soluble scFv expression}

Clones showing positivity/binding in phage ELISA were selected for soluble $\mathrm{scFv}$ expression. These were than transformed into HB2151 using calcium chloride mediated transformation for soluble scFv expression. The HB2151 cells carrying pCANTA-5E plasmid were grown in $10 \mathrm{ml}$ 
2XTY medium overnight at $37^{\circ} \mathrm{C}$ with shaking at $200 \mathrm{rpm}$. The next day, $1 / 100^{\text {th }}$ volume of the overnight culture was inoculated in 1 litre of $2 \mathrm{XTY}$ medium and grown at $37^{\circ} \mathrm{C}$ with shaking at $240 \mathrm{rpm}$ till the OD reached 0.6 and then the culture was induced by $1 \mathrm{mM}$ IPTG for 6 to $8 \mathrm{~h}$ at $24^{\circ} \mathrm{C}$ [33]. Cells were harvested and different fractions were prepared. scFvs were purified from the periplasmic fraction. Briefly, the cells were harvested by centrifugation at $4000 \times \mathrm{g}$ for $15 \mathrm{~min}$ at $4^{\circ} \mathrm{C}$. The supernatant was discarded and pellet was resuspended in $30 \mathrm{mM}$ Tris-Cl. $20 \%$ sucrose, $\mathrm{pH} 8.0$ at $80 \mathrm{ml} /$ gram wet weight. The cells were placed on ice for $20 \mathrm{~min}$ and $500 \mathrm{mM}$ EDTA was added to a final concentration of $1 \mathrm{mM}$ EDTA. The cells were spun down at $8000 \times \mathrm{g}$ for $15 \mathrm{~min}$ at $4^{\circ} \mathrm{C}$. The pellet was resuspended in $5 \mathrm{mM} \mathrm{MgSO}_{4}$ and the cells were placed on ice for $10 \mathrm{~min}$ with slowly stirring, pelleted down at $8000 \times \mathrm{g}$ for $15 \mathrm{~min}$ at $4^{\circ} \mathrm{C}$ and the supernatant collected for purification.

\section{Purification of E-tagged scFv}

Purification of E-tagged $\mathrm{scFv}$ was carried out using the Recombinant Phage Antibody System (RPAS) Purification Module (Amersham Biosciences) as per the manufacturer's instructions. The periplasmic extract was filtered through a $0.45 \mu \mathrm{m}$ filter to remove any remaining cell debris. The Anti-E Tag column was regenerated by washing the column with $15 \mathrm{ml}$ of elution buffer (0.1 M glycine, $\mathrm{pH} 3.0)$ and was then equilibrated with $25 \mathrm{ml}$ binding buffer $(0.02 \mathrm{M}$ phosphate buffer, $0.005 \% \mathrm{NaN}_{3}, \mathrm{pH} 7.0$ ). The E-tagged scFv in the periplasmic extract was then allowed to bind to the column by passing the extract through the column. The unbound excess E. coli proteins were removed from the column by washing it with $25 \mathrm{ml}$ binding Buffer. The flow rate at each step was maintained at $5 \mathrm{ml} / \mathrm{min}$ through the column. Finally, the bound scFv was eluted by $15 \mathrm{ml}$ elution buffer. Several fractions of the eluted $\mathrm{scFv}(900 \mu \mathrm{l}$ each) were collected in tubes containing $100 \mu$ l neutralization buffer (1 M Tris, $0.05 \%$ NaN3, pH 8.2). The amount of protein in each fraction was estimated using BCA method and the fractions containing considerable amount of $\mathrm{scFv}$ were pooled together and concentrated.

\section{Soluble ELISA}

Soluble ELISA was performed, as described in the phage ELISA. Hundred microliter of soluble $\mathrm{scFv}$ periplasmic extract/purified $\mathrm{scFv}$ was added and incubated at room temperature for $1 \mathrm{~h}$. ELISA plates were washed three times with $0.1 \%$ PBST and incubated with 1:1000 dilution of primary antibody in 2\% MPBS. The plates were washed three times with $0.1 \%$ PBST and incubated with 1:2000 diluted anti rabbit HRP conjugated secondary antibody in $2 \%$ MPBS. The ELISA plates were washed again as described above. $100 \mu \mathrm{l}$ of TMP substrate was added and incubated at RT till the colour developed. Reaction was stopped by adding $8 \mathrm{NH}_{2} \mathrm{SO}_{4}$. Absorbance was read at $450 \mathrm{~nm}$.

\section{SDS-PAGE and Western blot}

SDS-PAGE was done as described [33]. Proteins were separated on a $12 \%$ running gel and 5\% stacking gel and visualized by Coomassie Brilliant Blue (CBB) staining. For Western blotting, gel was blotted onto nitrocellulose membrane using electroblotting, (100 V for $1 \mathrm{~h}$ ) and probed with primary antibody. Anti-rabbit HRP was used as secondary antibody and colour was developed with $\mathrm{DAB}$ as the substrate.

\section{Competing interests}

The authors declare that they have no competing interests.

\section{Authors' contributions}

$\mathrm{KL}$ and SS designed and conceptualized the study and finalized the manuscript. RK constructed the phage library, constructed the scFvs and wrote the manuscript. RA screened the plasma of patients for neutralization and performed the EBV transformation experiments. AT provided valuable inputs in phage library construction. SSP, DD,AS and LK helped in protein expression, purification and phage ELISA. NW provided the patient samples. All authors have read and approved the final manuscript.

\section{Acknowledgements}

We thank the patient participant for providing blood sample. We profoundly thank Dr Susan Zolla Pazner from New York University for providing the antiparvovirus antibody 1418. We thank DBT (BT/PR 10511/MED/29/66/2008) for the funds and for the junior research fellowship provided to Rajesh Kumar. We thank All India Institute of Medical Sciences and National Brain Research Centre for providing the facilities for conducting this study.

\section{Author details}

${ }^{1}$ Department of Biochemistry, All India Institute of Medical Sciences, New Delhi, India. ${ }^{2}$ Department of Medicine, All India Institute of Medical Sciences, New Delhi, India. ${ }^{3}$ National Brain Research Centre, Manesar, India. ${ }^{4}$ Present address: Centre for Biodesign, Translational Health Science and Technology Institute, Gurgaon, India.

\section{Received: 2 May 2012 Accepted: 17 October 2012}

Published: 15 November 2012

\section{References}

1. Moulard M, Phogat SK, Shu Y, Labrijn AF, Xiao X, Binley JM, Zhang M-Y, Sidorov IA, Broder CC, Robinson J, Parren PWHI, Burton DR, Dimitrov DS: Broadly cross-reactive HIV-1-neutralizing human monoclonal Fab selected for binding to gp120-CD4-CCR5 complexes. Proc Natl Acad Sci USA 2002, 99:6913-6918.

2. Zolla-Pazner S, Zhong P, Revesz K, Volsky B, Williams C, Nyambi P, Gorny MK: The cross-clade neutralizing activity of a human monoclonal antibody is determined by the GPGR V3 motif of HIV type 1. AIDS Res Hum Retroviruses 2004, 20:1254-1258.

3. Burton DR, Pyati J, Koduri R, Sharp SJ, Thornton GB, Parren PW, Sawyer LS, Hendry RM, Dunlop N, Nara PL: Efficient neutralization of primary isolates of HIV-1 by a recombinant human monoclonal antibody. Science 1994, 266:1024-1027.

4. Gorny MK, Williams C, Volsky B, Revesz K, Wang X-H, Burda S, Kimura T, Konings FAJ, Nádas A, Anyangwe CA, Nyambi P, Krachmarov C, Pinter A, Zolla-Pazner S: Cross-clade neutralizing activity of human anti-V3 monoclonal antibodies derived from the cells of individuals infected with non-B clades of human immunodeficiency virus type 1. J Virol 2006 , 80:6865-6872.

5. Pantophlet R, Ollmann Saphire E, Poignard P, Parren PWHI, Wilson IA, Burton DR: Fine mapping of the interaction of neutralizing and nonneutralizing monoclonal antibodies with the CD4 binding site of human immunodeficiency virus type $1 \mathrm{gp} 120$. J Virol 2003, 77:642-658. 
6. Posner MR, Hideshima T, Cannon T, Mukherjee M, Mayer KH, Byrn RA: An IgG human monoclonal antibody that reacts with HIV-1/GP120, inhibits virus binding to cells, and neutralizes infection. J Immunol 1991 146:4325-4332.

7. Trkola A, Dragic T, Arthos J, Binley JM, Olson WC, Allaway GP, Cheng-Mayer C, Robinson J, Maddon PJ, Moore JP: CD4-dependent, antibody-sensitive interactions between HIV-1 and its co-receptor CCR-5. Nature 1996, 384:184-187.

8. Scheid JF, Mouquet H, Feldhahn N, Seaman MS, Velinzon K, Pietzsch J, Ott RG, Anthony RM, Zebroski H, Hurley A, Phogat A, Chakrabarti B, Li Y, Connors M, Pereyra F, Walker BD, Wardemann H, Ho D, Wyatt RT, Mascola $J R$, Ravetch JV, Nussenzweig MC: Broad diversity of neutralizing antibodies isolated from memory B cells in HIV-infected individuals. Nature 2009, 458:636-640.

9. Walker LM, Phogat SK, Chan-Hui P-Y, Wagner D, Phung P, Goss JL, Wrin T, Simek MD, Fling S, Mitcham JL, Lehrman JK, Priddy FH, Olsen OA, Frey SM, Hammond PW, Kaminsky S, Zamb T, Moyle M, Koff WC, Poignard P, Burton DR: Broad and potent neutralizing antibodies from an African donor reveal a new HIV-1 vaccine target. Science 2009, 326:285-289.

10. Wu X, Yang Z-Y, Li Y, Hogerkorp C-M, Schief WR, Seaman MS, Zhou T, Schmidt SD, Wu L, Xu L, Longo NS, McKee K, O'Dell S, Louder MK, Wycuff DL, Feng Y, Nason M, Doria-Rose N, Connors M, Kwong PD, Roederer M, Wyatt RT, Nabel GJ, Mascola JR: Rational design of envelope identifies broadly neutralizing human monoclonal antibodies to HIV-1. Science 2010, 329:856-861.

11. Gray ES, Meyers T, Gray G, Montefiori DC, Morris L: Insensitivity of paediatric HIV-1 subtype $C$ viruses to broadly neutralising monoclonal antibodies raised against subtype B. PLoS Med 2006, 3:e255.

12. Moore PL, Gray ES, Sheward D, Madiga M, Ranchobe N, Lai Z, Honnen WJ, Nonyane M, Tumba N, Hermanus T, Sibeko S, Mlisana K, Abdool Karim SS, Williamson C, Pinter A, Morris L: Potent and broad neutralization of HIV-1 subtype $C$ by plasma antibodies targeting a quaternary epitope including residues in the V2 loop. J Virol 2011, 85:3128-3141.

13. Gorny MK, Gianakakos V, Sharpe S, Zolla-Pazner S: Generation of human monoclonal antibodies to human immunodeficiency virus. Proc Natl Acad Sci USA 1989, 86:1624-1628.

14. Smith GP: Filamentous fusion phage: novel expression vectors that display cloned antigens on the virion surface. Science 1985, 228:1315-1317.

15. Pansri $P$, Jaruseranee $N$, Rangnoi $K$, Kristensen $P$, Yamabhai $M$ : A compact phage display human scFv library for selection of antibodies to a wide variety of antigens. BMC Biotechnol 2009, 9:6.

16. Winter G, Griffiths AD, Hawkins RE, Hoogenboom HR: Making antibodies by phage display technology. Annu Rev Immunol 1994, 12:433-455.

17. Bugli F, Graffeo R, Paroni Sterbini F, Torelli R, Masucci L, Sali M, Grasso A, Rufini S, Ricci E, Fadda G, Pescatori M: Monoclonal antibody fragment from combinatorial phage display library neutralizes alpha-latrotoxin activity and abolishes black widow spider venom lethality, in mice. Toxicon 2008, 51:547-554.

18. Andre F, Fröde D, Meyer T, Schirrmann T, Hust M: Generating Recombinant Antibodies for Research, Diagnostics and Therapy Using Phage Display. Current Biotechnology 2012, 1:33-41.

19. Kuwata T, Katsumata Y, Takaki K, Miura T, Igarashi T: Isolation of potent neutralizing monoclonal antibodies from an SIV-Infected rhesus macaque by phage display. AIDS Res Hum Retroviruses 2011, 27:487-500.

20. Kempf E, Weiss E, Klein P, Glacet A, Spratt S, Bourel D, Orfanoudakis G: The rescue by phage display of human Fabs to gp120 HIV-1 glycoprotein using EBV transformed lymphocytes. Mol Biotechnol 2001, 17:97-108.

21. Hemelaar J, Gouws E, Ghys PD, Osmanov S: Global and regional distribution of HIV-1 genetic subtypes and recombinants in 2004. AIDS 2006, 20:W13-W23.

22. Cardozo T, Kimura T, Philpott S, Weiser B, Burger H, Zolla-Pazner S: Structural basis for coreceptor selectivity by the HIV type 1 V3 loop. AIDS Res Hum Retroviruses 2007, 23:415-426.

23. Sharon M, Kessler N, Levy R, Zolla-Pazner S, Görlach M, Anglister J: Alternative conformations of HIV-1 V3 loops mimic beta hairpins in chemokines, suggesting a mechanism for coreceptor selectivity. Structure 2003, 11:225-236.

24. Hill CM, Deng H, Unutmaz D, Kewalramani VN, Bastiani L, Gorny MK, ZollaPazner S, Littman DR: Envelope glycoproteins from human immunodeficiency virus types 1 and 2 and simian immunodeficiency virus can use human CCR5 as a coreceptor for viral entry and make direct CD4-dependent interactions with this chemokine receptor. J Virol 1997, 71:6296-6304.

25. Wang WK, Dudek T, Essex M, Lee TH: Hypervariable region 3 residues of HIV type 1 gp120 involved in CCR5 coreceptor utilization: therapeutic and prophylactic implications. Proc Natl Acad Sci USA 1999, 96:4558-4562.

26. Andrabi R, Choudhary AK, Bala M, Kalra R, Prakash SS, Pandey RM, Luthra K: Relative reactivity of HIV-1 polyclonal plasma antibodies directed to V3 and MPER regions suggests immunodominance of V3 over MPER and dependence of high anti-V3 antibody titers on virus persistence. Arch Virol 2011, 156:1787-1794.

27. Andrabi R, Bala M, Kumar R, Wig N, Hazarika A, Luthra K: Neutralization of tier-2 viruses and epitope profiling of plasma antibodies from human immunodeficiency virus type 1 infected donors from India. PLoS One 2012, 7:e43704.

28. Krebber A, Bornhauser S, Burmester J, Honegger A, Willuda J, Bosshard HR, Plückthun A: Reliable cloning of functional antibody variable domains from hybridomas and spleen cell repertoires employing a reengineered phage display system. J Immunol Methods 1997, 201:35-55.

29. Gorny MK, Sampson J, Li H, Jiang X, Totrov M, Wang X-H, Williams C, O'Neal T, Volsky B, Li L, Cardozo T, Nyambi P, Zolla-Pazner S, Kong X-P: Human anti-V3 HIV-1 monoclonal antibodies encoded by the VH5-51/VL lambda genes define a conserved antigenic structure. PLoS One 2011, 6:e27780.

30. David D, Goossens D, Desgranges C, Thèze J, Zouali M: Molecular characterization of human monoclonal antibodies specific for several HIV proteins: analysis of the VH3 family expression. Immunol Lett 1995, 47:107-112.

31. Wisnewski A, Cavacini L, Posner M: Human antibody variable region gene usage in HIV-1 infection. J Acquir Immune Defic Syndr Hum Retrovirol 1996, 11:31-38.

32. Chahboun $\mathrm{S}$, Hust M, Liu Y, Pelat $T$, Miethe $\mathrm{S}$, Helmsing $\mathrm{S}$, Jones RG, Sesardic $D$, Thullier $P$ : Isolation of a nanomolar scFv inhibiting the endopeptidase activity of botulinum toxin $A$, by single-round panning of an immune phage-displayed library of macaque origin. BMC Biotechnol 2011, 11:113.

33. Burmester J, Spinelli S, Pugliese L, Krebber A, Honegger A, Jung S, Schimmele B, Cambillau C, Plückthun A: Selection, characterization and $x$-ray structure of anti-ampicillin single-chain Fv fragments from phage-displayed murine antibody libraries. J Mol Biol 2001, 309:671-685.

34. Rangnoi K, Jaruseranee N, O'Kennedy R, Pansri P, Yamabhai M: One-step detection of aflatoxin-B(1) using scFv-alkaline phosphatase-fusion selected from human phage display antibody library. Mol Biotechnol 2011, 49:240-249.

35. Little M, Welschof M, Braunagel M, Hermes I, Christ C, Keller A, Rohrbach P Kürschner T, Schmidt S, Kleist C, Terness P: Generation of a large complex antibody library from multiple donors. J Immunol Methods 1999, 231:3-9.

36. Okamoto T, Mukai Y, Yoshioka Y, Shibata H, Kawamura M, Yamamoto Y, Nakagawa S, Kamada H, Hayakawa T, Mayumi T, Tsutsumi Y: Optimal construction of non-immune scFv phage display libraries from mouse bone marrow and spleen established to select specific scFvs efficiently binding to antigen. Biochem Biophys Res Commun 2004, 323:583-591.

37. Vaughan TJ, Williams AJ, Pritchard K, Osbourn JK, Pope AR, Earnshaw JC, McCafferty J, Hodits RA, Wilton J, Johnson KS: Human antibodies with subnanomolar affinities isolated from a large non-immunized phage display library. Nat Biotechnol 1996, 14:309-314.

38. Bose B, Chugh DA, Kala M, Acharya SK, Khanna N, Sinha S: Characterization and molecular modeling of a highly stable anti-Hepatitis B surface antigen scFv. Mol Immunol 2003, 40:617-631.

39. Zhang MY, Shu Y, Rudolph D, Prabakaran P, Labrijn AF, Zwick MB, Lal RB, Dimitrov DS: Improved breadth and potency of an HIV-1-neutralizing human single-chain antibody by random mutagenesis and sequential antigen panning. J Mol Biol 2004, 335:209-219.

40. Montefiori DC: Measuring HIV neutralization in a luciferase reporter gene assay. Methods Mol Biol 2009, 485:395-405.

41. Seaman MS, Janes H, Hawkins N, Grandpre LE, Devoy C, Giri A, Coffey RT, Harris L, Wood B, Daniels MG, Bhattacharya T, Lapedes A, Polonis VR, McCutchan FE, Gilbert PB, Self SG, Korber BT, Montefiori DC, Mascola JR: Tiered categorization of a diverse panel of HIV-1 Env pseudoviruses for assessment of neutralizing antibodies. J Virol 2010, 84:1439-1452.

42. Tiwari A, Khanna N, Acharya SK, Sinha S: Humanization of high affinity anti-HBs antibody by using human consensus sequence and 
modification of selected minimal positional template and packing residues. Vaccine 2009, 27:2356-2366

43. Caputo JL, Thompson A, McClintock P, Reid YA, Hay RJ: An effective method for establishing human B lymphoblastic cell lines using epstein-barr virus. Methods Cell Sci 1991, 13:39-44.

44. Traggiai E, Becker S, Subbarao K, Kolesnikova L, Uematsu Y, Gismondo MR, Murphy BR, Rappuoli R, Lanzavecchia A: An efficient method to make human monoclonal antibodies from memory $B$ cells: potent neutralization of SARS coronavirus. Nat Med 2004, 10:871-875.

45. NCBI: Ig BLAST. http://www.ncbi.n/m.nih.gov/igblast/.

46. Althaus H-H, Müller W, Tomlinson I: V BASE. http://vbase.mrccpe.cam.ac.uk/.

doi:10.1186/1472-6750-12-87

Cite this article as: Kumar et al:: A novel strategy for efficient production of anti-V3 human scFvs against HIV-1 clade C. BMC Biotechnology 2012 12:87.

\section{Submit your next manuscript to BioMed Central and take full advantage of:}

- Convenient online submission

- Thorough peer review

- No space constraints or color figure charges

- Immediate publication on acceptance

- Inclusion in PubMed, CAS, Scopus and Google Scholar

- Research which is freely available for redistribution 